\title{
Inevitability and contingency: the political economy of Brexit ${ }^{1}$
}

Placing Britain's vote on 23 June 2016 to leave the European Union in historical time raises an immediate analytical problem. What was clearly the result of a number of contingencies, starting with the 2015 general election where we can see how events could readily have turned out otherwise and was a shock to the British government that had not prepared for this outcome might also represent the inevitable end of Britain's membership of the EU seen from the distant future. This paper seeks to take both temporal perspectives seriously. It aims to provide an explanation of the vote for Brexit that recognises the referendum result as politically contingent and also argue that the political economy of Britain generated by Britain's position as non-euro member of the EU whilst possessing the offshore financial centre of the euro zone and Britain's eschewal in 2004 of transition arrangements on freedom of movement for A8 accession states made Brexit an eventual inevitability, saving a prior collapse of the euro zone.

\section{Keywords: Brexit, European Union, Cameron, the euro, freedom of movement}

Britain's vote on 23 June 2016 to leave the European Union (EU) presents a temporal paradox. Seen from the distant future, Brexit is likely to appear the inevitable outcome of the long history of Britain's membership of the EU and its predecessors. Britain joined a partial economic union whose rules had been determined by others, when that union became a currency union it was unwilling to sacrifice monetary sovereignty and opted-out, and when that currency union produced an economic crisis that both required more political union and had spill-over effects for Britain, membership was rendered unsustainable. Symbolically, this torturous path from problematic membership through partial withdrawal to secession reached its end when, although trying to keep Britain inside the EU, David Cameron negotiated an opt-out of the ever closer union that is the EU's stated raison d'étre. Yet judging Brexit from the present, the outcome of the referendum was experienced as a shock by much of the British political class. Moreover, seen in short- to medium-term time, the path to Brexit required a set of contingencies to occur: Cameron had to promise to include a referendum pledge in the Conservatives' 2015 manifesto; the Conservatives had to win enough seats to form another government; and the other EU states had to refuse to make significant concessions to the British government in the renegotiations; and the Leave campaign had to win the referendum.

Here, I ask whether or not Brexit was inevitable, taking into account both of these temporal perspectives. The point of departure used for the shorter time frame is the return of the Conservatives to office in May 2010. Contrary to those who insist that Cameron precipitated an unnecessary crisis of

\footnotetext{
${ }^{1}$ My thanks to the participants at the workshop at Edinburgh on 23-24 February 2017 for this special edition for their helpful comments on the first draft of this paper in particular John Peterson, Graham Wilson, and Dan Wincott, and also to Josh Simons for incisive criticism of parts of the argument.
} 
Britain's membership by calling an avoidable referendum (Glencross, 2016; Saunders, 2016; Vail, 2015), I argue that the underlying structural forces generated by Britain's singular macro-political economy created a relatively high degree of probability that the denouement of Britain's membership of the EU would be reached under the conditions of the Conservative party being in office.

There are a number of limitations to this argument. First, Britain's singular macro-political economy is not the only possible starting place in looking for structural fault-lines in Britain's EU membership. Britain can easily be seen as a country with a singular European history in relation to the continent (Adler-Nissen et al 2017: 6-7). One could argue that given the long-standing difficulties of reconciling Britain's constitutional tradition to the EU a democratic reckoning was eventually inevitable, especially once the governance of England had been rendered incoherent by asymmetric devolution (Henderson et al 2016). After the Maastricht Treaty was ratified without a plebiscite, it is quite possible that Britain's membership could be sustained only so long as British governments could avoid holding any EU referendum. A 'no' vote would have been likely whatever the question on the ballot paper. If it had been on a treaty, any attempt to have Britain vote again as had occurred in other member states, would have probably failed and triggered a crisis.

Second, whatever the effect of structural fault-lines, political agency matters too. As a matter of judgement, British governments had long avoided drawing any conclusion about inexorable impediments to successful membership. They made sacrifices - over fishing -, engaged in futile attempts to change the EU's course - the hard ecu proposal -, and ignored the ways opt-outs were diluted - the Charter of Fundamental Rights - because they wished first to gain and then preserve membership. British governments kept Britain inside the EU by kicking problems down the road. As Jim Bulpitt (1992: 260) noted, most of the behaviour of Conservative governments 1961 to 1991 exhibited not defeatism but "hyper-optimism in presenting the benefits of Community membership as regards both the British economy and Britain's international power pretensions'. In significant part, this strategy for dealing with membership arose because of the strong preference of successive governments of both parties to see the issue in terms of Britain's geo-political position in the world (Gamble 2003; Wilson 2017). This desire was exhibited by the Macmillan government's initial pursuit of European Economic Community (EEC) membership to appease the Kennedy administration (Kaiser, 1999). It was also evident in Cameron's reported remark to Daniel Hannan, in rejecting the argument that a trading relationship within the EU was insufficient, that he thought Britain 'get[s] a 
greatly amplified voice through having a common foreign policy' (Quoted in Shipman, 2016: loc 2309). Given the potential loss of British international influence (Dee and Smith 2017) it is quite possible that no British Prime Minister would ever have demurred from the judgement that Britain geo-politically should be in a functioning EU and rejected subjecting that judgement to a referendum.

Third, for all the historical problems of domestic consent to British EU membership, Brexit at this point in time turned on a referendum in which only around 600000 people would have had to vote otherwise to produce a different outcome. The 'Leave' campaign initially appeared disadvantaged in political resources. But it ran a superior operation in mobilising votes and devised an effective message around 'let's take back control' chosen from an array of rather less potent options pressed upon it. Even at a point of subsequent crisis, if a British government had decided Britain should leave the EU, it would still have had to win a referendum. Whatever problems of high politics EU membership has generated for British governments, many voters have positions and emotions around the EU that exist entirely independent of them. Referendums inherently offer no guarantees to governments.

The analysis is divided into three sections. The first considers the long-term macro-political economy of Britain's EU membership and its political consequences. The second explains in general terms how, as a consequence of this divergence of interests, the 2008 financial crash and the eurozone crisis changed the economic and political context of Britain's EU membership. It then shows how these general problems manifested themselves in a succession of policy conflicts between the British government and other member states, the ECB, and the European Commission in which British influence was weak. The third assesses the contingencies in play from May 2010 to the renegotiations in February 2016, by posing two counter-factual questions. One concerns Cameron's decision in January 2013 to promise a referendum, and the other is in terms of the renegotiations. The final section draws some conclusions.

\section{Macro-economic outsider}

Britain's accession to the EEC immediately created general economic problems from trade to agriculture to fishing. Consequently, British governments lacked shared interests with other memberstates. In a Community led by a Franco-German axis, British governments frequently lacked allies. Politically, Britain became, in Stephen George's (1998) words, an 'awkward partner', in Stephen 
Wall's (2008), a 'stranger in Europe', and in Jim Bulpitt's (1992: 269) 'the permanent minority member'.

Of course, these initial problems were not the sum total of Britain's EU membership. As time passed, each became less important. Economically, the pattern of British trade shifted away from the Commonwealth towards the EU, and the second Thatcher government was able to reduce Britain's budget contributions. Indeed, on a number of particular issues British governments did secure political victories, and a number of EU policies, particularly in regard to the Single European Market (SEM), strongly reflected British preferences (Menon and Salter, 2016: 1300).

Nonetheless, even as trading convergence took place and British political influence increased there was one economic issue that left Britain in a singular position within each formation of the EU: from the onset of EEC membership to the impending end of EU membership, British governments have not wanted to Europeanise monetary and exchange rate matters. The Heath government was willing to sacrifice a great deal to procure EEC membership. Even so, before accession Heath took Britain out of the EEC's first common exchange rate policy, the Snake. The Heath government was far from alone in the 1970s in fearing the monetary cost of maintaining a stable exchange rate with West Germany. But only Ireland, whose currency was then formally tied to sterling, gave up on the Snake as quickly as Britain. Indeed, several states made several attempts to make Snake membership work. Moreover, the British government was alone in 1978 in eschewing membership of the Exchange Rate Mechanism (ERM). This time the Irish government chose to abandon its sterlingbased currency regime to join the collective arrangement.

This singular approach to monetary policy caused undoubted domestic problems for British governments in the 1980s. Although British governments enjoyed a more flexible approach to inflation and fiscal policy than the ERM states, sterling remained prone to crisis and the British economy frequently had to endure a higher real rate of interest for a given level of inflation than the ERM states (Thompson, 1996). By the second half of the 1980s these problems led most of Margaret Thatcher's senior colleagues to support ending Britain's monetary isolationism. As the third Thatcher government struggled with the advantages and disadvantages of ERM membership monetary union appeared on the EC agenda, hugely raising the stakes of Britain's monetary position. Indeed, the prospect of the single currency and the immediate pressure put on exchange rate management by these discussions in 1988-1990 helped to make it ultimately impossible for Thatcher to resist her colleagues' pressure 
for sterling's entry to the ERM. Rejecting the single currency risked accepting a two-tier EC in which Britain would become a marginal member-state and possibly the loss of London's status as Europe's premier financial centre to Frankfurt. Thatcher was in a clear minority in her Cabinet in wishing simply to reject monetary union as an unacceptable loss of monetary sovereignty.

Nonetheless, after her colleagues dispensed with Thatcher in an internal party coup, the apparently logical consequence that the monetary course should change proved extremely problematic. Contrary to the hope of some of Thatcher's ministers, there was no possibility that a British government could change the terms of the monetary union debate. It was shaped by confrontation between French frustration at German monetary hegemony inside the ERM and the price the German government demanded for substituting a European central bank for the Bundesbank. When the choice Thatcher had understood would arise was laid bare, her successor, John Major, was able to commit at Maastricht only to possible future accession to monetary union. Moreover, the end of sterling's ERM membership in September 1992 destroyed any realistic chance of this accession. The governments of other ERM states also found the experience of subordination to German monetary policy in 1992-93 intolerable. Most suspended their narrow currency bands with the Deutschmark in July 1993. But their credibility was hugely invested in the commitment to move to a single currency. They sought to repair the ERM as a path to that end. By contrast, with the striking exception of Tony Blair most senior members of the Conservative and Labour parties saw Black Wednesday as the death knell for British participation in all European monetary experiments, whether for political influence within the EU or short-term sterling stability.

A renewed bout of sterling weakness could have put the renewed attachment to monetary sovereignty to the test after 1992. In practice, however, sterling lost its propensity to crisis from mid1995. Inflation remained significantly lower than for much of the 1980s for the remainder of the decade. In this changed monetary context, non-membership of the euro was much less threatening than non-membership of the ERM had been in the second half of the 1980s. Consequently, during New Labour's first two administrations, Gordon Brown and the Treasury had little difficulty marshalling decisive arguments about the loss of macro-economic autonomy that membership of the single currency would have entailed against Blair's apparent wish to use entry to increase British influence within the EU (Buller, 2014). Indeed, as the euro-zone states lost macro-economic discretion after the onset of the single currency, British governments and the Bank of England were better equipped to 
exploit Britain's long-standing macro-economic flexibility, pushing British interests further away from other member-states. Johnston and Regan (2016: 319) have argued monetary union ended the coexistence of distinct 'inflation-prone and inflation-moderating growth regimes' within the participating parts of the EU. Consequently, non-euro membership ensured Britain retained a singular political economy that, in accommodating some moderate inflation, allowed for higher average growth than the euro-zone. Between 1996 and 2007 Britain enjoyed a higher growth rate than the euro-zone average except in 2000, 2006 and 2007, than Germany except in 2006 and 2007, and than France in all but 1998, 1999, 2000 and 2004 (World Bank, 2016). Meanwhile the fears of some in the Thatcher and Major governments that non-membership would jeopardise the City of London's position proved unfounded. Indeed, by the turn of the century the City had become the offshore centre of euro trading (Roberts, 2005: 309).

This singular macro-political economy was reinforced by the decision of the Blair government to forgo transitional restrictions on the freedom of movement in relation to the accession in 2004 of the A8 states. A judgement by the New Labour government, in particular Blair himself, about Britain's position in the EU provided part of the motive underlying this decision. Having both stayed out of the euro and strongly supported the accession of the eastern European states, Britain should commit to an integrationist position regardless of the interests at stake (Watt and Wintour, 2015). Especially since no other large-economy state followed suit, the consequences of this decision went far beyond the search for influence. High levels of migration from much lower-wage economies changed Britain's labour markets. The new supply of eastern European labour acted as check on wages, as the Treasury explicitly recognised in its case for forsaking transition arrangements, (Wright, 2010: 16566). Implementing freedom of movement immediately after A8 accession was a corollary of the potentially inflationary consequences of retaining monetary sovereignty. As such, it entrenched what under conditions of economic stress would become a domestically unpopular EU commitment (Milazzo and Goodwin 2017) into the structure of the British macro-political economy. Ultimately, this move weakened the basis of domestic political support for Britain's EU membership. It divided British interests both from those of other relatively high-employment northern European states that did adopt transition arrangements, most significantly Germany, and those eastern European states that had every interest in defending their citizens' access to the British labour market.

Prior to 2008 the overall effect of this singular macro-political economy was to create fault-lines 
through Britain's membership of the EU but not to generate crises. A potential initial crisis over monetary union during the negotiations leading to Maastricht was avoided by Major's decision to defer judgement on membership; and a possible crisis once the euro began was sidestepped by the conjunction of good fortune around sterling and the City's underlying international strengths. Indeed, in using the opt-out in the context of a Treaty to avoid an early decision on monetary union, the Major government established a template used by New Labour when dealing with unwelcome proposals for increased EU authority and formalising existing British discretion. Moreover, both the Conservative and New Labour governments successfully managed these fault-lines without recourse to the electorate. Here Blair enjoyed considerable fortune. When migration from eastern Europe proved far higher than the government had forecast, circumstances allowed him to discard his 2005 referendum promise on the proposed EU constitution.

\section{Everything changes}

The 2008 financial crash and the euro-zone crisis from late 2009 put immense pressure on these macro-political economy fault-lines. Economically, the two crises pushed British interests further away from other member-states. First, compared to the European Central Bank (ECB), the Bank of England's response to the financial crash was much more expansionary. Whilst the Bank of England began Quantitative Easing (QE) in 2009 and has yet to raise interest rates, the ECB did not pursue QE until 2015 and raised interest rates twice in 2011. Second, the British economy was slower initially to recover from the 2008-9 recession. British growth lagged behind the euro-zone average in 2010 and France and Germany in 2011. But, from 2012, when the euro-zone as a whole sunk back into recession, the British economy grew significantly faster than the other large EU states (World Bank, 2016). Third, the euro-zone crisis changed EU migration patterns in a manner that directly impacted Britain. Except for Italy, the crisis effectively ended migration from eastern states of the EU into the euro-zone periphery. It also generated significant migration from the periphery to Germany and Britain, while before 2009 there was little (Bräuninger, 2014: 1, 5). ONS (2015) data shows EU immigration to Britain starting to rise in the fourth quarter of 2012 - as the divergence in growth between Britain and the euro-zone materialised. It rose less from the A8 states than the EU15 that included the euro-zone periphery. Put more schematically, the euro-zone crisis made Britain, with Germany, a joint employer of last resort for a monetary union of which it was not a member when 
Britain's population had been rising since the turn of the century.

In political terms, the financial crash and the euro-zone crisis were equally consequential. First, the problems of the euro-zone politicised London's position as the euro's offshore financial centre. They created a view elsewhere in the EU, as (Whyte, 2012: 7) has noted, that 'the City of London and unregulated Anglo-American finance must be tamed if the single currency is to survive'. Second, the euro-zone crisis ensured that there would be a renewed drive towards integration driven by the needs of the currency union. This reality was made clear in the Four Presidents' Report of 2012 and the Five Presidents' Report three years later, which said that the viability of the euro depended on completing economic, financial, fiscal and political union by 2025, and that financial union required legislative changes impacting on all EU member states (Juncker, 2015: 4-5, 12). Third, the euro-zone crisis significantly expanded Germany's political influence within the EU (Bulmer, 2014; Paterson, 2011). More particularly, Germany acquired a new means of making side-payments to other member-states. The German government could now choose whether or not to offer concessions to other memberstates through bailouts and support for the Commission's macro-economic surveillance and new ECB policy measures when tacit German acquiescence including through the German Constitutional Court became, in effect, a condition for the ECB's authority to act. As Beach (2013: 125) has noted, nothing can happen in managing the euro-zone crisis without 'German acceptance for any form of transfer'. Fourth, under euro-zone crisis conditions the British government was unable to mobilise the other non-euro member-states into a political bloc. The Danish krona was already tied to the euro in monetary policy terms through ERM2 membership. In 2009 the Danish government flirted with a referendum on joining the euro. For its part, the Swedish central bank moved its monetary policy closer to that of the ECB as the euro-zone crisis developed, raising interest rates with the ECB in 2011 and adopting QE only in 2015. Moreover, as the euro-zone states came to agree a set of policy responses to the crisis, from the Fiscal Compact treaty to Banking Union, except Britain, all the noneuro states signed up to at least one initiative. Indeed, some have accepted the principle of granting an ECB role in supervision of their banks without having a place on the ECB Governing Council.

These developments left British governments with a strategic problem. The dilemma was explicitly recognised by Cameron (2012) in an article published in the Daily Telegraph in June 2012. Britain, Cameron argued, needed the EU for the SEM and foreign policy co-operation 'to maximise our influence in the world' and in other matters it required 'less Europe'. By contrast, he continued, 
'the single currency is driving a process that will see its members take more and more steps towards fuller integration'. The question left for Britain was, he said, 'how do we avoid the wrong paths of either accepting the status quo meekly or giving up altogether and preparing to leave?'

Cameron's initial response to this predicament was to try to use the integrationist dynamics generated by the euro-zone crisis to secure new political protections for Britain on financial matters. He also sought to reverse some previous shifts in sovereignty in other policy areas. As William Hague, the then Foreign Secretary, explained in the House of Commons' debate on an EU referendum in October 2011:

We have agreed in the coalition that our first priority in responding to treaty changes aimed at stabilising the euro-zone will be to protect the rights of those countries in the EU but outside the euro-zone over decisions affecting them, and to prevent damage to the financial services industry that is so important to this country's economy. ... It is my view and the Prime Minister's view, and the position of the Conservative party, that we will use future opportunities to bring further powers back to the United Kingdom - to repatriate powers to the United Kingdom in those areas where we believe European integration has gone too far (Hansard, 2011: col 54).

In other words, from potentially tipping Britain towards a crisis of membership, the Coalition government sought to turn the euro-zone crisis into an opportunity.

In practice, however, as an approach to the strategic dilemma, this tactic was forlorn. A number of policy episodes between 2010 and 2015 demonstrated both the depth of Britain's political weakness inside the EU under conditions of a euro-zone crisis and how Cameron's own approach to the domestic political problems of EU membership undermined his attempt at reform. Issues arising from London's position as the offshore-financial centre of the euro-zone began these policy problems. In July 2011 the ECB issued a policy paper stating that clearing houses handling more than five per cent of euro-denominated product should be located within the euro-zone. Since most euro clearing was done in London, a move to this 'locational policy', as it became known, would certainly have resulted in London losing business (Fleming, 2014). In contesting the proposal, the Coalition government fell back on the European Court of Justice (ECJ), invoking the argument that the ECB's proposal in discriminating between euro-zone and non-euro-zone members violated the freedoms enshrined in the SEM. In March 2015 the ECJ sided with the British government, ruling that the ECB did not have the authority to regulate clearing house activities. Nonetheless, the Court refused to rule on the overriding claim about non-discrimination, leaving Britain without an established legal principle for future battles (Barker and Stafford, 2015).

This fraught legal position was compounded over the issue of bailouts for euro-zone states. In 
December 2010 the Coalition government agreed that there could be a legal foundation within the EU as a whole for the creation of the European Stability Mechanism (ESM) in exchange for what Cameron said was a watertight commitment that Britain would not participate in euro-zone bailouts and an end to the European Financial Stability Mechanism (EFSM), which obligated all EU members to participate in bailouts. Cameron was keen to present the termination of the EFSM as a triumph, with the Conservatives' 2015 manifesto proclaiming that ending participation in the fund was 'the first ever return of powers from Brussels' (Conservative Party, 2015: 72). However, this EFSM agreement had no legal force, and during the Greek crisis of the summer of 2015 the Commission revived the fund. With decisions on ESFM operating under Qualified Majority Voting, and the euro-zone states constituting a majority, the Conservative government was unable to block the move (Barker et al, 2015). Instead, it had to reach a new agreement with the euro-zone states that any liabilities to noneuro-zone states arising from the EFSM would be covered by an ECB cash fund. Reaching this accommodation in July 2015, the government also extracted a promise that the principle that noneuro-zones would not have to participate in bailouts would be written into EU law (BBC News, 2015). Again, however, the agreement was not load-bearing. The issue had to be included in the renegotiations in 2016, the outcome of which again only included a further promise to address EU law on the matter in the future.

In the case of the Financial Transactions' Tax, the conflict between the British position and that of the most powerful euro-zone states exposed the weakness inherent to Cameron's whole strategy for changing the terms of British membership. In the autumn of 2011 the conjunction of a proposal for a Financial Transactions' Tax - 60 per cent of the revenues from which would have accrued in Britain (Seely, 2014: 13) -, and Angela Merkel's apparent desire for a new treaty to deal with euro matters led Cameron to believe that he had his chance to exploit the euro-zone crisis to British advantage. In the run-up to the Brussels summit on 8-9 December 2011 Cameron told the House of Commons:

'There is the option of a treaty at 27 , where we have the ability to say yes or no and as a result get a price for that, but there is also always the possibility that the euro-zone members at 17 will go ahead and form a treaty of their own. Again, we have some leverage in that situation, because they need the use of EU institutions, but we should recognise exactly what our leverage is and make the most of it' (Hansard, 2011: col 293).

In practice, however, this leverage was non-existent. Cameron demanded a side-agreement that would, among other things, have scrapped the ECB's locational policy and created a national veto in 
the whole policy area of financial services in exchange for making the Fiscal Compact part of EU law. He then found that Merkel was insufficiently wed to a new treaty to concede anything. In Britain any new treaty would have been subject to a referendum under the $2011 \mathrm{EU}$ Act, so it is difficult to see how Merkel could have wanted a treaty with British participation. The next month the Coalition government was presented with a fait accompli when 25 EU states agreed the Treaty on Stability, Coordination, and Governance in the Economic and Monetary Union, of which the Fiscal Compact is a part. The Treaty included powers for the Commission and the ECJ to which, under EU and international law, the British government should have given its prior agreement (Dehousse, 2012). In response the Coalition government simply acquiesced, saying only that it reserved the right to take legal action if British interests were threatened by the use of the EU institutions within the Treaty (House of Commons, 2012: 16). Put more schematically, Cameron's negotiating strategy during this episode was entirely dependent on an EU treaty that the German government did not need to achieve its aims. Cameron's weak position did not end with the Treaty on Stability, Co-ordination, and Governance in the Economic and Monetary Union. Even Britain's non-participation in the Fiscal Pact was not absolutely accepted elsewhere within the EU. The Five Presidents' Report stated that for the euro-zone to be put on a sustainable basis the Treaty on Stability, Co-ordination, and Governance should be put into EU law (Juncker, 2015: 12).

Given the exposure of Britain's weak position in relation to the euro-zone crisis, it is probably not surprising, as Schelkle (2016: 159-60) has noted, that the Coalition government chose not to oppose the European Council's banking union agreement of June 2012. Nonetheless, in this instance, the consequences of not resisting intensified British weakness. The new initiative implied the creation of two tiers of financial services within the SEM. It increased the shared interests of euro-zone states and other member-states that agreed to enter it into a close co-operation agreement with the ECB as part of the Single Supervisory Mechanism (SSM) (Whyte, 2012). The new political risk generated by British acquiescence was demonstrated in September 2012 by Commission proposals to reform the London-based European Banking Authority (EBA) in light of the SSM. The Coalition government responded with an intense political effort to reverse the Commission's voting proposals for the EBA. It appeared to secure an agreement in December 2012 that decisions made by the EBA would require a majority of SSM and non-SSM members. Nine months later, however, the Commission was still 
contesting the compromise, and the issue was not put to rest until December 2013 (Barker and Singer, 2012; Barker, 2013).

The cumulative effect of these episodes was to reveal how much political pressure the 2008 financial crash and the euro-zone crisis had come to place on Britain's position in the SEM, which stood as one of the two principal rationales for Britain's EU membership. In response to these difficulties, the Coalition government was forced to improvise defensively. It had no opportunity within the politics of the euro-zone crisis to engage in a serious way with the implications for Britain of eurozone-generated integration, especially since it was done without a new EU treaty. The subsequent extemporisation included both a flight to the ECJ and a push for new voting rules on financial services and banking matters. Indeed, the House of Commons' Foreign Affairs Committee 2013 report into the government's EU policy took the view that the government's actions showed it 'now consider[ed] that protecting the UK's interests in the SEM may no longer be possible under qualified majority voting, and that tougher decision-making thresholds may be required, ... represent[ing] a significant shift in the position which the UK has held on the Single Market since the Single European Act' (Quoted in UK Government, 2013: 4). In its rejoinder to this report, the Coalition government effectively conceded the underlying difficulty, simultaneously insisting that membership of the EU was in 'the national interest' and that 'the EU must reform' without any explanation of how reform that would end the need for defensive improvisation could be achieved (UK Government, 2013: 1).

\section{Plausibly otherwise?}

Cameron made two crucial judgements that set the path to the referendum outcome, and each raises a counter-factual question of whether he could have plausibly decided otherwise. The first question is: could Cameron have managed EU matters in relation to his leadership of the Conservative party without promising a referendum? Here we must start with the 2010 Conservative party manifesto, which formed the basis of the commitments Cameron took into the coalition negotiations with the Liberal Democrats. The manifesto included a referendum lock on any Treaty that gave new powers to the EU, a sovereignty bill that would 'make it clear that ultimate authority stays in this country', and a promise to renegotiate the return of various powers from the EU to Westminster, which logically had to involve negotiations for either a new treaty or revision of an existing one (Conservative Party, 2010: 114). Whilst the sovereignty bill was dropped as part of the Coalition agreement, the other two 
commitments were brought into government, with the 2011 EU Act entrenching the referendum lock. The consequence of this Act was effectively to render impossible the commitment to renegotiate the transfer of power in EU treaties to change the terms of Britain's membership. Moreover, since this move was treaty dependent, it bankrupted the strategy of securing opt-outs deployed by British governments since Maastricht to deal with difficult issues. After passage of the $2011 \mathrm{EU}$ Act, other EU governments must have understood that any new treaty would probably be defeated in a British referendum and almost certainly also that reversing a referendum result by ignoring it would be extremely difficult.

Cameron ran into exactly this impasse at the December 2011 summit. He did not, however, seem to understand its significance. Cameron's Bloomberg speech in January 2013 promising the referendum was premised on the hope that a renegotiation could be secured through a new treaty. He insisted the EU would need a treaty 'to make the changes needed for the long-term future of the Euro' (Cameron, 2013). In this sense, Cameron did make a strategic mis-calculation. But the alternative would have been de facto admission to his party that his commitment to reform Britain's EU membership was meaningless. Moreover, the significance of the December 2011 episode was not lost on those Conservatives pressing for a referendum, who were already emboldened by the backbench rebellion on David Nuttall's Commons' referendum motion two months earlier. Some Conservatives interpreted Cameron's failure in December 2011 in the starkest terms. Anthony Browne (2011), an advisor to Boris Johnson, wrote on Conservative Home, 'faced with a choice between an EU treaty to save the euro and retaining control of regulation of the City, President Sarkozy decided to retain regulation of the City'. It is dubious whether this conclusion did follow because of the problem generated for other states by the referendum lock. Yet there could be no possible incentive for Cameron to acknowledge that the referendum lock was a source of British weakness.

The Conservative Party's (2010: 21) 2010 manifesto also included a promise to reduce immigration to a target and to 'limit access only to those who will bring most value to the British economy'. This commitment quite obviously clashed with EU law. From the onset it was thus unrealisable without treaty change. Once significant immigration from the euro-zone periphery began in 2012, it also became a political liability, fuelling the rise of UKIP (Goodwin and Malazzo 2017). In the month before Cameron's referendum promise 11 of 27 surveys in the UK Polling Report (2016) 
had UKIP ahead of the Liberal Democrats. 6 had the Conservatives at less than 30 per cent. Again, Cameron's reaction - the Bloomberg speech- in a sense was odd in this particular political context as he did not include freedom of movement as an issue for renegotiation. Yet choosing to persist with the existing immigration policy commitment and treating EU reform as a matter that could be dropped was incoherent and a growing domestic political risk to the Conservative party and ultimately democratic consent to EU membership.

Certainly, any claim that Cameron could not plausibly have chosen otherwise would be hard to make. Most notably, George Osborne, who was confronting largely the same array of structural constraints as the Prime Minister, strongly opposed offering a referendum. Nor is there any evidence that Cameron clearly deliberated over the dilemmas in play by the end of 2012 in a way that showed he had mastered their complexity. Nonetheless, by whatever means internally he reached that calculation, Cameron was correct in judging that the path he had embarked upon on taking office was exhausted. In such circumstances, it would have been difficult to avoid the referendum promise if he did not wish to provoke a leadership challenge after the European Parliament elections or to eschew the chance of winning the general election. This view is, of course, one pushed by those close to Cameron (Oliver, 2016: 9, 395; Shipman, 2016: loc 525-541). But it is not clearly wrong, especially since UKIP won its victory in the European Parliament elections and its two by-elections in the 201015 parliament after the referendum promise was made. George Osborne might have urged Cameron otherwise, but that judgement can just as readily be construed as denial of changed circumstances as it can superior thinking about the risks ahead. The euro-zone crisis had derailed the government's initial fatally-flawed EU strategy and exposed British political weakness inside the EU..

Cameron's referendum decision can be seen as a gamble premised on one or other or of three assumptions: first that there was no prospect of the Conservative party winning the 2015 general election; second that the other EU member-states, in particular Germany, would not risk Britain leaving now the impasse had been elevated to crisis level; and third that there was no realistic chance of a Leave vote winning. The first of these possibilities seems intrinsically unlikely. Moreover, Cameron subsequently committed himself in the 2015 Conservative Party (2015: 72) manifesto to forsaking leading a future coalition agreement with the Liberal Democrats, which was always a plausible outcome of the 2015 general election, unless it included a referendum pledge. If Cameron wanted room for manoeuvre he would have had to relinquish the Conservative leadership without any 
reason to suppose that his successor could have dropped the promise and retained sufficient parliamentary support to enable another coalition. The second and third must be considered together in relation to the second counter-factual question: could Cameron have secured a renegotiation that in its outcome would have had a realistic chance of changing the referendum result? Given the weaknesses during the referendum campaign shown by the Remain side and the opportunities taken by the Leave side on immigration and the sovereignty issue around it, the question issue here is whether there were ever sufficient incentives for the German government - taken for analytical purposes here to rest on Merkel's judgement - to offer Cameron what he most needed from the renegotiations, namely a way of exercising some kind of control over EU migration.

If we start here with Merkel's judgement of German national interests, Germany did have something to lose from a British exit from the EU, namely one fewer northern European ally on economic issues and the prospect of increased budget contributions. Looked at in terms of the overall credibility of the EU, the possible loss of the Union's second largest economy and most significant military power was also a clear negative. Nonetheless, at both levels of interests, the euro-zone crisis had also rendered Britain's membership an ongoing structural problem. Britain was irrelevant to the euro-zone issue and presented a de facto block on any further treaty change. By mid-2015 this reality was brought into clear focus by the Five Presidents' Report. Among other things, it had asserted that new legislation was required on the Capital Markets Union, an agreement of all member-states, as an essential component of financial union for the euro-zone states (Juncker, 2015: 12). Seen in these terms, what mattered for the outcome of the renegotiations was whether Merkel thought she had to spend political capital to obtain an outcome that was probably on balance desirable but ensured certain ongoing disadvantages and for which she was likely to pay a domestic price.

Certainly, in 2013 and 2014 Cameron apparently did think Merkel would offer a compromise to keep Britain inside the Union. As one person involved in the internal discussions told Tim Shipman (2016: loc 587):

'A number of people in Number 10 - including the PM - suspected deep down that, when it came to it, in the early hours of a European Council meeting, the EU wouldn't let the UK leave on the basis of a temporary emergency brake'.

Yet when it became clear that Merkel was unhappy with him putting a demand for an emergency brake into his planned speech on immigration in the autumn of 2014 Cameron backed down and concentrated his demands on access to benefits and a commitment that migrants from other EU 
states could come to Britain only if they held a job offer (Shipman, 2016: loc 602-631). Then when Cameron (2015) wrote his letter to Tusk in the autumn of 2015 he did not ask even for discussion on the job offer requirement and concentrated only on benefits. By not asking Cameron never did put Merkel to the test.

Whether or not he misjudged what might have been gained from a confrontation, Cameron's reluctance to push Merkel to the point where she would have had to decide on, and pay for, an accommodating outcome did reflect the political weakness of Britain's position inside the EU from 2008. This weakness had been all too evident in Cameron's inability to stop Jean-Claude Juncker's appointment as President of the European Commission in June 2014, despite his initial belief he had Merkel's support on the issue (Peterson, 2016: 355-6). When Cameron warned that the appointment increased the likelihood that his promised referendum would end Britain's EU membership, Merkel told him not to 'threaten' her (Quoted in Swinford, 2014). Apparently bruised by that experience, five months later Cameron (2014) eschewed threats in his immigration speech for the language of pragmatic optimism:

'The entire EU is built on a gift for compromise. ... Only this month, a way was found to accommodate France breaching its budget deficit limit, as everyone knew it would be, and it can be done again.'

But the reality was that concessions that were necessary to manage euro-zone state relations were not required when demanded by a non-euro-zone state.

The palpable limits this reality put on the renegotiations themselves then helped to make the case for a Leave vote. Constructing an argument during the referendum about reform achieved by Cameron through Britain's weight inside the EU was extremely difficult. British preferences appeared irrelevant to the EU's future and Germany's seemed decisive. Cameron's failure to shift Merkel's position on immigration reinforced an impression of rising German power, fuelled during 2015 by the humiliation of the Syriza government over the third Greek bailout and Merkel's decision to rip up the Dublin Convention over refugees. This impression was intensified in the first half of 2016 by Merkel's lead role in securing the EU agreement with Turkey that closed the Balkan refugee/migrant route (Streeck, 2016). Put differently, if the second possible assumption Cameron made in deciding on a referendum - Germany would not let Britain leave the EU - was invalid then the third possible assumption - a referendum could not be lost - was also inoperative. 
Whatever the tactical limitations of Cameron's approach to the renegotiations, the problems that ongoing British membership posed for the euro-zone states was a hard constraint on the possible outcomes. As Osborne reportedly said in the summer of 2015, 'Britain h[e]ld very few of the cards' in the renegotiations (Quoted in Shipman, 2016: loc 2994). This problem was not the accidental product of Cameron's personal failings or the idiosyncrasies of his judgement in relation to his party. Rather it was the inevitable consequence of trying to secure concessions in a political context without treaty negotiatons. There was now nothing self-evidently at stake for the German government independently of the questions of its commitment, or not, to maintaining Britain's EU membership.

\section{Conclusions}

In a number of ways, the 2008 financial crash and the euro-zone crisis put a time-bomb under the sustainability of Britain's membership of the EU. They generated conflict over London's position as the offshore financial centre of the euro, escalated the differences between the macro-economic options open to Britain and euro-zone states, produced a significant rise in immigration from the eurozone periphery into Britain, strengthened German influence within the EU, and weakened Britain's position in the SEM in regard to financial services and banking matters. These structural conflicts and constraints would have caused significant problems even to a non-Conservative led government. Their interaction with the set of commitments made by the Conservatives in their 2010 manifesto caused the Conservative-led Coalition and then the majority Conservative government particularly acute problems. These commitments were both unrealisable - the immigration target - and in practice contradictory - the referendum lock and the wish to use a new treaty to return some powers to Westminster. Cameron's failed attempt to reform the rules on financial services' decision-making in December 2011 and the subsequent Treaty on Stability, Co-ordination, and Governance in the Economic and Monetary Union acutely demonstrated the reality of the contradiction. Given the Five Presidents' Report and the obvious need for the euro-zone states to pursue further integration, these constraints on British influence could only have deepened if Britain were to remain an EU member. Any attempt to address the practical policy problems they generated - whether the risk of discrimination within the SEM or the particular consequences of freedom of movement for Britain in relation to a monetary union of which it was not a member - could only risk demonstrating the 
fundamental political weakness of Britain's position inside the EU and erode domestic democratic consent to it.

The one contingency from the path from May 2010 to 23 June 2016 that had little to do with Britain's position in the EU was the 2015 general election. If Labour had been able to form a government, there would have been no referendum. The fact that it did not was primarily a result of Labour's collapse in Scotland and the opportunity that gave the Conservatives in England. Once the Conservatives won their majority in 2015, the fact that the denouement of Britain's membership of the EU was then reached during the 2015-2020 Parliament was probable, but not inevitable. Whilst Cameron's decision to offer a referendum in January 2013 was a gamble that others might not have made and he did collectively eschew pushing Merkel into a decisive confrontation, his options at these crucial points of decision-making were narrow. Once his treaty-premised strategy had been bankrupted by the Fiscal Compact episode - whether he understood that to be the case or not -, he had no strategy available to reform the EU to British advantage. Indeed, even the defensive moves he thought the government had secured on bailouts and the EBA had to be refought and were insecure so long as there was no treaty in which they could be entrenched, a problem in itself which was in part the product of his own domestic push for the 2011 referendum lock. In this sense, Cameron made the Leave campaign's case - that there was little control to be had inside the EU - for it. Those campaigning to Leave still had to seize their opportunity, a task that was undoubtedly made easier by the contingencies of Boris Johnson's decision to join and Dominic Cummings' strategic thinking (Shipman 2016). It is, however, very hard to see how a narrow vote to Remain would have settled the issue, or done anything other than elevate to Conservative leadership someone promising to revisit the question. Only if Cameron could have released himself from the desire to win the 2015 election, an act of self restraint almost always beyond politicians, could he have escaped from the diminution of decision-making options and, consequently, bought British membership of the EU significantly more time.

\section{References}

Adler-Nissen at al (2017) Performing Brexit: how a post-Brexit world is imagined outside the UK. British Journal of Politics and International Relations. xxxx

Barker A (2013) UK demands hold up banking union. Financial Times, 11 October. Available at: https://www.ft.com/content/0f2d8c8a-3281-11e3-b3a7-00144feab7de (accessed 27 March 2017).

Barker A and Singer P (2012) UK close to clinching bank union safeguards. Financial Times, 12 
December. Available at: https://www.ft.com/content/fd51e37a-4489-11e2-8fd7-00144feabdc0 (accessed 27 March 2017).

Barker A Spiegel P and Parker G (2015) David Cameron frustrated at UK dragged into Greece bailout. Financial Times, 15 July. Available at https://www.ft.com/content/6d92bbe2-2b0411e5-8613-e7aedbb7bdb7 (accessed 27 March 2017).

Barker A and Stafford P (2015) Victory for UK over eurozone clearing houses. Financial Times, 4 March. Available at: http://www.ft.com/cms/s/0/425aeee0-c24f-11e4-bd9f00144feab7de.htm|\#axzz3v32O1XRn (accessed 27 March 2017).

BBC News (2015) UK "strikes deal" over Greek bailout. 16 July. Available at: http://www.bbc.co.uk/news/uk-politics-33556085 (accessed 27 March 2017).

Beach D (2013) The fiscal compact, euro-reforms and the challenge for the euro-outs. In: N. Hvdit and H. Mouritzen (eds) Danish Foreign Policy Yearbook. Copenhagen: Danish Institute for International Studies, pp. 113-133.

Bräuninger D (2014) The dynamics of migration in the euro area. Deutsche Bank, 14 July. Available at: https://www.dbresearch.com/PROD/DBR_INTERNET_EN-

PROD/PROD0000000000338137/The+dynamics+of+migration+in+the+euro+area.PDF

Browne A (2011) France and Germany could have had their treaty but they wanted control of the City instead. Conservative Home, 9 December. Available at http://www.conservativehome.com/thecolumnists/2011/12/anthony-browne-france-andgermany-could-have-had-their-treaty-but-they-decided-to-push-for-control-o.html (accessed 27 March 2017).

Buller J (2014) The importance of being autonomous: understanding the Blair government's policy towards the single currency. British Politics 9 (3): 318-345.

Bulmer S (2014) Germany and the eurozone crisis: between hegemony and domestic politics. West European Politics 37 (6): 1244-1263.

Bulpitt J (1992) Conservative leaders and the "Euro-ratchet": five doses of scepticism. Political Quarterly 63 (3): 258-275.

Cameron D (2012) We need to be clear about the best way of getting what is best for Britain. Daily Telegraph, 30 June. Available at:

http://www.telegraph.co.uk/news/politics/david-cameron/9367479/David-Cameron-We-need-to-beclear-about-the-best-way-of-getting-what-is-best-for-Britain.html (accessed 27 March 2017).

Cameron D (2013) EU speech at Bloomberg. Speech given at Bloomberg, London, 23 January. Available at https://www.gov.uk/government/speeches/eu-speech-at-bloomberg (accessed 27 March 2017).

Cameron D (2014) JCB Staffordshire: Prime Minister's speech. Speech given at JCB Staffordshire, 28 November. Available at: https://www.gov.uk/government/speeches/jcb-staffordshire-primeministers-speech (accessed 27 March 2017).

Cameron D (2015) A new settlement for the United Kingdom in a reformed European Union. Letter to Donald Tusk, 10 November. Available at:

https://www.gov.uk/government/uploads/system/uploads/attachment data/file/475679/Donald Tusk letter.pdf (accessed 27 March 2017).

Conservative Party (2010) Invitation to Join the Government of Britain. London: Conservative Party.

Conservative Party (2015) Strong Leadership, a Clear Economic Plan, a Brighter More Secure Future. London: Conservative Party.

Dee M and Smith K (2017) UK diplomacy at the United Nations after Brexit. British Journal of Politics and International Relations. xxxx 
Dehousse R (2012) The "fiscal compact": legal uncertainty and political ambiguity,' Notre Europe Policy Brief No 33 (February). Available at:

http://www.institutdelors.eu/media/fiscalpact r.dehousse ne feb2012.pdf?pdf=ok (accessed 27 March 2017).

Fleming S (2014) UK and ECB set to clash in court over clearing houses. The Financial Times, 9 July. Available from http://www.ft.com/cms/s/0/17c32a34-06bc-11e4-ba3200144feab7de.html\#axzz3uxsq6e5D

Gamble A (1993) Between Europe and America: The Future of British Politics. London: Palgrave Macmillan.

George S (1998) An Awkward Partner: Britain in the European Community, third edition. Oxford: Oxford University Press.

Glencross A (2016) Why the UK Voted for Brexit: David Cameron's Great Miscalculation. London: Palgrave Macmillan.

Goodwin M and Milazzo C (2017) Taking back control: investigating the role of immigration in the vote for Brexit. British Journal of Politics and and International Relations. xxxxx

Hansard (2011a) National referendum on the European Union. The House of Commons, 24 October.

Hansard (2011b) Prime Minister's Question Time. The House of Commons, 7 December.

Henderson A et al (2016) England, Englishness and Brexit. The Political Quarterly 87 (2): 187-199.

House of Commons (2012) Parliamentary briefing: the treaty on stability, co-ordination, and governance in the economic and monetary union. Research Paper 12/14, 27 March.

Kaiser W (1999) Using Europe, Abusing the Europeans: Britain and European integration 1945-1963. London: Palgrave Macmillan.

Johnston A and Regan A (2016) European monetary integration and the incompatibility of national varieties of capitalism. Journal of Common Market Studies 54 (2): 318-336.

Juncker J-C. (2015) The five Presidents' report: completing Europe's economic and monetary union. Report, European Commission. Available at: https://ec.europa.eu/priorities/sites/betapolitical/files/5-presidents-report en.pdf (accessed 27 March 2017).

Menon A and Salte J-P (2016) Brexit: initial reflections. International Affairs 92 (6): 1297-1318.

Oliver C (2016) Unleashing Demons: The Inside Story of Brexit. London; Hodder and Stoughton.

ONS (2015) Key Data: long-term International migration, rolling annual data for the United Kingdom, year ending June 2015. Available at:

http://webarchive.nationalarchives.gov.uk/20160105160709/http://www.ons.gov.uk/ons/taxono my/index.html?nscl=Migration (accessed 27 March 2017).

Paterson WE (2011) The reluctant hegemon?: Germany moves centre stage in the European Union. Journal of Common Market Studies 49 (Annual Review): 57-75.

Peterson J (2017) Juncker's political European Commission and an EU in crisis. Journal of Common Market Studies 55 (2): 349-367.

Roberts R (2005) London as an international financial centre 1980-2000: global powerhouse or Wimbledon EC2? In: Cassis Y and Bussière E (eds) London and Paris as International Financial Centres in the Twentieth Century. Oxford: Oxford University Press. 
Saunders R (2016) A tale of two referendums 1975 and 2016. Political Quarterly 87 (3): 318-322.

Schelke W (2016) Financial centre and monetary outsider: how precarious is the UK's position in the EU? Political Quarterly 87 (2): 157-165.

Seely A (2014) The Tobin tax: recent developments. UK Parliament Briefing Papers, 15 May.

Shipman T (2016) All Out War: The Full Story of How Brexit Sank Britain's Political Class. London: William Collins. Kindle edition.

Streeck W (2016) Exploding Europe: Germany, the refugees and the British vote to leave. SPERI Paper No 31. Available at http://speri.dept.shef.ac.uk/wp-content/uploads/2016/09/SPERIPaper-31-Wolfgang-Streeck-Exploding-Europe.pdf

Swinford S (2014) Don't threaten me over Juncker appointment, Angela Merkel warns David Cameron. Daily Telegraph, 10 June.

Thompson H (1996) The British Conservative Government and the European Exchange Rate Mechanism. London: Pinter.

UK Government (2013) The future of the European Union: UK Government policy. Government Response to the House of Commons Foreign Affairs Committee Report HC 87 of Session 2013-14. Available at:

https://www.gov.uk/government/uploads/system/uploads/attachment data/file/236744/32689 C m 8693 v0.4.pdf (accessed 27 March 2017).

UK Polling Report (2016) Voting intention since 2016. Report, UK Polling Report. Available at: http://ukpollingreport.co.uk/voting-intention-2 (accessed 27 March 2017).

Vail MI (2015) Between one-nation Toryism and neoliberalism: the dilemmas of British conservatism and Britain's evolving place in Europe. Journal of Common Market Studies 53 (1): 106-122.

Wall S (2008) A Stranger in Europe: Britain and the EU from Thatcher to Blair. Oxford: Oxford University Press.

Watt $\mathrm{N}$ and Wintour P (2016) How immigration came to haunt Labour: the inside story. Guardian, 24 March. Available at:

https://www.theguardian.com/news/2015/mar/24/how-immigration-came-to-haunt-labour-inside-story (accessed 27 March 2017).

Wilson G (2017) The UK, USA and Brexit. British Journal of Politics and International Relations. XXxx

Whyte P (2012) What a banking union means for Europe. Centre for European Reform, December. https://www.cer.org.uk/sites/default/files/publications/attachments/pdf/2012/essay bankingunion 5de c12-6704.pdf (accessed 27 March 2017).

Wright C (2010) The regulation of European labour mobility: national policy responses to the free movement of labour transition arrangements. SEER Journal for Labour and Social Affairs in Eastern Europe 13 (2): 157-179.

World Bank (2016) Development Data, World Databank. Available at:

http://databank.worldbank.org/data/home.aspx (accessed 27 March 2017). 